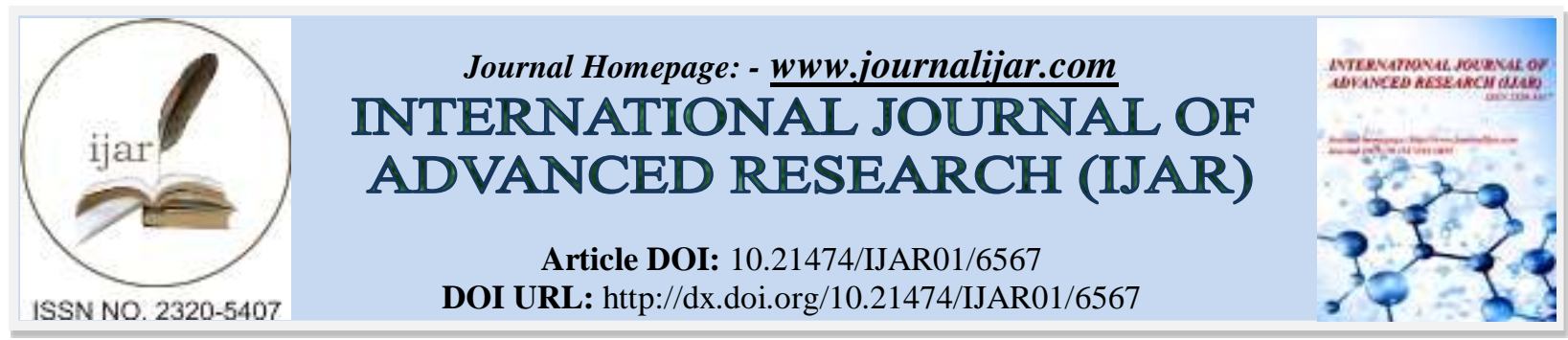

RESEARCH ARTICLE

\title{
EFFECTIVENESS IN USING INQUIRY-BASED TEXTBOOK OF PHYSICS FOR PHYSICS LEARNING IN VOCATIONAL HIGH SCHOOL.
}

Faiz Nour Rohmah, Indrawati, I Ketut Mahardika, Sutarto, Joko Waluyo and Nuriman.

Faculty of Teacher training and education, Jember University, East Java, Indonesia.

\section{Manuscript Info}

Manuscript History

Received: 17 December 2017

Final Accepted: 19 January 2018

Published: February 2018

Key words:-

textbook, inquiry, efectiveness, learning outcome, student response.

\begin{abstract}
This research aimed to describe the effectiveness in using inquiry-based textbook of Physics for Physics Learning in Vocational High School. The effectiveness was reflected by student learning outcomes and responses after the implementation of inquiry-based textbook of Physics. The research method was quasi-experimental research with design of One Group Pre-test Post-test. The subjects of the research were students of X Multimedia odd semester, Vocational High School Al-Qodiri Jember. Data collection techniques were the test of student learning outcome and questionnaire. Data analysis techniques used Ngain to analyze the improvement of the learning outcomes and percentage to determine student responses. The results showed that the $\mathrm{N}$-gain score on the first, second and third learning material was 0.61 in moderate category; 0.74 in high category; and 0.72 in high category. Based on the data analysis of student response,the overall student response was $84 \%$ and it was in positive category. Based result of research,the conclusion is inquiry-based textbook of Physics was effective for Physics learning in Vocational High School as reflected by the average of $\mathrm{N}$-gain score which was in high category and student responses were in positive category.
\end{abstract}

Copy Right, IJAR, 2018,. All rights reserved.

\section{Introduction:-}

Learning is an interaction process between the learners andteachers and the learning resources in a learning environment. The learning process of curriculum 2013 is based on a concept that learning is a process of potential and character development of each learner as the result of the synergy between education that takes place at schools, families, and society (Kemdikbud, 2014). The learning characteristics of curriculum 2013 include student-centered learning and the use of scientific approach within the learning activities covering observing, questioning, collecting data, associating, and communicating what have been discovered through the analysis.

The curriculum 2013 learning develops an education process, where students develop knowledge, thinking skills, and psychomotor skills through direct interaction with learning resources that have been designed by the teacher in the lesson plan. The teacher as an educator must realize that a teacher's primary profession is not in his ability to develop science, but rather his ability to carry out meaningful learning in learners. therefore teachers must understand how to learn, to ease learning for student and also be a creative, professional and fun in the class(Mulyasa, 2010). 
The nature of physics is the science that studies the phenomena of a series of processes known scientific process that is built on the basis of the scientific attitude and the results are manifested as a scientific product that is composed of the three most important components are concept, principles and theories that apply universally (Trianto , 2012). Physics is one part of science. The process of physics learning should relate physics concepts with physical phenomena in life and should be directed to do and find out so can help students to get a extensive knowledge (Depdiknas, 2006). So that physics is not just accept science information but better if in teaching and learning activities students are given direct experience that is in the form of observation or investigation of existing natural phenomena.

The Vocational high school level, physics lessons in the curriculum 2013 including adaptive subjects where is subjects that support basic vocational subjects. Based on observations and interviews that have been done to some teachers of Vocational high school in Jember, one of the indication of low learning outcomes in learning physics students of Vocational high school is the existence of student learning resources is worksheet which only describes a number of materials that must be memorized by students and has not contained some characteristics of curriculum 2013. Worksheet has not developed students' resolve problems encountered, so that students are still difficult to use his acquired knowledge when attributed to daily life and vocational practice.

Inquiry-based physics textbook is a textbook containing the material description of physics class $\mathrm{X}$ one semester level of Vocational high school by using step of inquiry learning model. Inquiry learning is a learning that involves maximally all the ability of learners to search and investigate something systematically, critically, logically, analytically so that they can formulate their own invention with confidence (Mudlofir and Rusydiyah, 2015). The steps of implementation of inquiry learning according to sanjaya (2011: 201) as follows.

a. Formulate the problem is the first step in learning which takes students on problems that contains a puzzle and encourage students to find the right answer.

b. Formulate the hypothesis is a temporary answer to a problem under study. One way teachers can develop hypothetical skills in each child is to ask questions that encourage students to formulate a temporary answer.

c. Collecting Data is an activity seeking information needed to test the hypothesis that has been proposed. The role and role of teachers in this stage is to ask questions that can encourage students to think about finding the information needed.

d. Testing Hypotheses is the process of determining which answers are deemed to be accepted in accordance with the data or information obtained on the basis of data collection.

e. Formulating Conclusions is the process of describing the findings obtained based on the results of hypothesis testing.

Inquiry -based textbooks provide a process of inquiry to find truth, information, and knowledge in which students are encouraged to engage directly in inquiry, formulate problems, conduct experiments, collect and analyze data, draw conclusions, discuss and communicate. It is expected that students can find a concept, so that in preparing the experimental design done on its own ability. Inquiry-based textbooks aim to provide learners with the opportunity to gain experience, investigate their own problems by using skills appropriate to the scientific method. Based on inquiry, the learned concepts studied are found by the learners themselves. Through inquiry, learners are also trained to develop the skills of the science process; starting from the lowest stage, ie observing the integrated process skills stage, such as the ability to plan and conduct investigations. Simultaneously, students' scientific attitudes are also nurtured and developed during the learning process of science. Inquiry-based learning also provides opportunities to develop language skills for learners through activities of communicating the results of activities, both orally and in writing. Thus the learning process can avoid learning that is only centered on the teacher.

\section{Research Methods:-}

The research method was quasi-experimental research with design of One Group Pre-test Post-test. According Sugiyono (2011), test the effectiveness of using One Group Pre-test Post-test Design is with a class using inquiry based textbooks of physics with pretest at the start of learning and posttest at the end of the lesson. Data collection techniques used are the test results of student learning and questionnaires. The test is used to determine learning outcomes and a student response is used to measure students' opinions on textbooks that have been applied and given to students after completing all learning activities. Data analysis techniques use $\mathrm{N}$-gain and percentage to determine student response. Gain score is technical analysis to determine the level of increase learning outcomes from before using inquiry -based textbooks of physics and after using textbooks. 


\section{Results and Discussion:-}

Based on the results of data processing research, description of cognitive learning results obtained through the value of pre-test and post-test then calculated using $N$-gain can be seen in Table 1.

Table 1:- Data on student learning outcomes

\begin{tabular}{|l|l|l|l|l|l|}
\hline \multirow{2}{*}{ Number } & \multirow{2}{*}{ Material } & Average Value & \multirow{N}{*}{-gain } & \multirow{2}{*}{ Category } \\
\cline { 3 - 4 } & & Pre-test & Post-test & & \\
\hline 1 & The first material & 19,18 & 69,40 & 0,63 & Medium \\
\hline 2 & The second material & 14,31 & 77,86 & 0,76 & High \\
\hline 3 & The Third material & 18,95 & 77,04 & 0,75 & High \\
\hline \multicolumn{2}{|l|}{ The average score } & 17,48 & 74,76 & 0,71 & High \\
\hline
\end{tabular}

The first learning outcome, the material given is a straight-line magnitude. The learning outcomes for an average pre-test score of 19.18 and a post-test average score of 69.40. After analysis, average $\mathrm{N}$-gain on the first material is worth 0.63 in the medium category. The learning use inquiry -based textbook of physics is considered effective if the value of $\mathrm{N}$-gain learning outcomes fall into the high category, therefore it is necessary to test again on the second material. The second meeting with Regular Straight Motion material improved learning outcomes. Student learning outcomes on the second material for the average pre-test value of 14.31 while the post-test value of 77.86 . After the analysis, the $\mathrm{N}$-gain on the second material is worth 0.76 with a high category.

Based on the second data inquiry-based physics textbook is considered feasible and effective in improve student learning outcomes, but it should be re-examined in order to determine more effectively with third-conducting material. Student learning outcomes on the third material for the average pre-test score of 18.95 while the post-test value of 77.04 . After the analysis, the $\mathrm{N}$-gain on the third material is worth 0.75 with the high category. Based on the improvement of learning achievement, physics-based instructional inquiry is effectively used in school learning.

The last data taken in this research is students' responses to learning using inquiry -based textbooks of physics. Student response data to inquiry-based physics textbooks was obtained by giving a student response questionnaire after completing all learning activities. Questionnaire responses were analyzed with the following assessment: (a) score 1 represents the answer "Yes" to the positive statement and the answer "No" to the negative statement; (b) the score 0 represents the answer "No" to the positive statement and "Yes" to the negative statement. Data of student response result can be seen in Table 2 .

Table 2:- Student response to textbook

\begin{tabular}{|l|l|l|}
\hline No & Statement & Assessment \\
\hline 1 & The language is used in inquiry-based physics textbooks is easy to understand & $77 \%$ \\
\hline 2 & How to learn use inquiry-based physics textbook is very interesting & $90 \%$ \\
\hline 3 & $\begin{array}{l}\text { Opportunity to discuss in inquiry-based physics textbook makes me more daring to express } \\
\text { opinions }\end{array}$ & $68 \%$ \\
\hline 4 & The experimental stages in inquiry-based physics textbook make me more active learning & $72 \%$ \\
\hline 5 & This inquiry-based physics textbook helps me to understand physics more easily & $86 \%$ \\
\hline 6 & learning use inquiry-based physics textbook makes me more motivated & $86 \%$ \\
\hline 7 & The problems in inquiry-based physics textbook are difficult to understand & $90 \%$ \\
\hline 8 & The material presented in inquiry-based physics textbook is complete enough & $81 \%$ \\
\hline 9 & Learning to use inquiry-based physics textbook is boring & $100 \%$ \\
\hline 10 & I agree if an inquiry-based physics textbook is used as a teaching material in physics & $90 \%$ \\
\hline the average score of student responses & $84 \%$ \\
\hline
\end{tabular}

\section{Discussion:-}

This research is conducted by applying inquiry-based physics textbook in learning as a learning resource on linear motion kinematics material. There are three materials in the trial that is the amount of motion straight, straight uniform motion, and straight motion changes regularly. Based on the value of $\mathrm{N}$-gain obtained in the first material of 0.61 with the category is experiencing an increase in the second material of 0.76 with high category. This is because students are getting used to using textbooks and understand the steps that must be done. Then on the third material test the value of $\mathrm{N}$-gain of 0.75 with high category. When compared with the second material, $\mathrm{N}$ - gain score has 
decreased but still meet the criteria of the textbook is considered feasible because it is still in high category. This is in accordance with Habsary research (2016) which shows that there is an increase in student learning outcomes with an average $\mathrm{N}$-gain of 0.75 included in the high category by using Guided inquiry-based learning module.

Based on N-gain data obtained, the application of physics-based textbooks inquiry in the learning process in the classroom has an impact on improving student learning outcomes. This is because in the learning process, students are required to construct the knowledge gained through direct involvement to conduct an inquiry so as to provide experience to students in digging unknown information and prove the truth of a concept. In the process of investigating students doing discovery activities to solve the problem formulated, this can generate many ideas and ideas both the same and different from a group of friends so as to develop, add and enrich students' thinking skills in solving and finding solutions to these problems.

The learning disable in teacher inquiry model appropriate use textbooks developed and act as a facilitator, to direct students acquire new knowledge to develop the knowledge that has been previously owned. Student learning outcomes can be improved from before the application of physics-based textbooks to inquiry and student responses including positive categories, this means learning is fun, supported by research by Marlistya et al. (2016) which indicates that students are happy to follow the learning by using worksheet of development because it is something new for the students.

Student responses are measured using a student response questionnaire given after all learning activities have ended. Based on the analyst is student response data, obtained the percentage of overall student response by $84 \%$ and included in the positive category. This means the learning process using physics-based textbooks inquiry is fun, because students feel challenged to find answers to the problem formulated, directly involved in doing inquiry, thus reducing the saturation in learning. Based on the improvement of the learning achievement and the positive response of the students, the inquiry-based physics textbook is effective and worthy of use in school learning.

\section{Conclusion:-}

Based on the result or research, the inquiry-based textbook of Physics was effective for Physics learning in Vocational High School as reflected by the average of N-gain score which was in high category and student responses were in positive category. Based on result data of research that for other researchers, inquiry-based textbook of Physics can be used as a reference in the development of other materials so that obtained more information about the effectiveness of learning.

\section{References:-}

1. Almuntasheri, S., et al. 2016. The Effectiveness of a Guided Inquiry-based, Teachers 'Professional Development Program on Saudi Students' Understanding of Density. Science Education international journal. Vol.27 (1): 16-39.

2. Depdiknas. 2006. Guidelines for Writing Textbook, Explanation of Quality Standard of Indonesian Language Book. Jakarta; Center perbukuaan, Departement National Education

3. Habsary, AM, et al. 2016. The development of inquiry-based biology learning modules is guided by environmental pollution materials to empower the skills of the science process and students' interpretive thinking skills. Jurnal Inkuiri. Vol.5 (3): 122-132.

4. http://jurnal.fkip.uns.ac.id/index.php/sains

5. Kemdikbud. 2014. Permendikbud No. 104 Year 2014 on Learning on Disdakmen. Jakarta: Ministry of Education and Culture.

6. Marlistya, H., AD Lesmono, S. Wahyuni, and Maryani. 2016. Development of physics student activity sheet based on empirical inductive learning cycle model in SMA. Jurnal Pembelajaran Fisika. Vol.5 (2): 177-181.

7. http://jurnal.unej.ac.id/index.php/JPF/article

8. Mudlofir, A. \& Rusydiyah, EV. 2016. Innovative Learning Design: From Theory to Practice. Jakarta: PT RajaGrafindo Persada.

9. Mulyasa, 2013. Development and Implementation of Curriculum 2013. Bandung: PT Remaja Rosdakarya.

10. Sanjaya, W. 2010. Planning and Design of Learning System. Jakarta: Kencana Prenada Media Group.

11. Santyasa, I W. 2007. Innovative Learning Models. Presented on training on Classroom Action Research for Junior and Senior High School Teachers, June 29-July 1, at Nusa Penida.

12. Sugiyono. 2011. Quantitative Research Methodology, Qualitative, and $R \&$ D. Bandung. AlfabetK.

13. Trianto. 2012. Learning Model Integrated: Cons, Strategies, and Implementation in KTSP. Jakarta: Earth Literacy. 